\title{
The Role of Budget Decision Making as A Mediation of Accounting Information Systems and Organizational Culture on The Performance of Government Agencies
}

\author{
Setyani ${ }^{1^{*}}$, Imam Abu Hanifah ${ }^{2}$, lis Ismawati ${ }^{3}$ \\ $1^{*, 2,3}$ University of Sultan Ageng Tirtayasa ${ }^{1^{*}, 2,3}$ \\ Corresponding Author: setyani1982@gmail.com ${ }^{1 *}$
}

Keywords : Performance of Government Agencies, Budget Decision Making, Accounting Information Systems, Organizational Culture

\begin{abstract}
:
This research aims to analyze the role of budget decision making as a mediation of accounting information systems and organizational culture on the performance of government agencies. This research uses a survey method with a questionnaire instrument to collect data. Data collection in this research was carried out by distributing questionnaires to respondents directly.

The results of this research indicate that first, the accounting information system has no effect on the performance of government agencies. Second, organizational culture has a significant positive effect on the performance of government agencies. Third, the accounting information system has a significant positive effect on budget decision making. Fourth, organizational culture has a significant positive effect on budget decision making. Fifth, budget decision making has a significant positive effect on the performance of government agencies. Sixth, budget decision making is not mediated the relationship of accounting information systems to the performance of government agencies. Seventh, budget decision making mediated the relationship between organizational culture and the performance of government agencies.
\end{abstract}




\section{Introduction}

In recent times, local governments have often been described as low-productivity and inefficient organizations. Local governments are required to prove their performance is not limited to financial performance, but non-financial performance in the form of outputs and outcomes for the use of existing resources. The government must be able to provide information on financial performance and non-financial performance in an accountable manner to assist the government in making economic, social and political decisions. Performance accountability is increasingly needed in line with the globalization process which requires the government to create clean government and good government in improving the performance of the public sector.

Community demands to realize clean government and good government are inversely proportional to the issues that exist in the Regional Apparatus Organizations (RAO) in the government. As the results of the evaluation of the Banten Province Government Agency Performance Accountability System (SAKIP) in 2020 which showed that the improvement in the quality of bureaucratic performance culture development and results-oriented governance in the Banten Provincial government was not significant and still needs to be improved. This is caused by the level of effectiveness and efficiency of budget use which is still low when compared to performance achievements. In addition, based on the results of the evaluation of SAKIP for the last 2 (two) years, the performance of the Banten Provincial government has not increased. Therefore, the government should be motivated to improve its performance as a form of its commitment in providing services to the community.

As a steward of the community, the government must be able to show better performance in order to continue to gain the trust of the community to manage existing resources. The level of service to the community is one indicator that can be used as a benchmark for government performance. However, this is precisely what is more often the cause of the failure to achieve government performance. As happened in 2020, namely the corruption case in the procurement of masks for handling COVID-19 at the Banten Provincial Health Office (regional.kompas.com, 2021). The procurement of masks is intended for the benefit of the community in the context of handling COVID-19. The corruption case itself involved 20 State Civil Apparatus (SCA) officials from echelon III and echelon IV in the Banten Province Health Office.

The level of budget discipline that is still lacking indicates that the work culture embedded in the organization is still low. According to De Long and Fahey (2017), it is stated that organizational culture is needed to increase knowledge sharing and creative thinking to support organizational success. This statement is in line with the results of research conducted by Fadhlurrohman, Budiman, and Khairina (2021), Sadad, Pituringsih, and Irwan (2016), and 
Syahputri et al., (2019), namely organizational culture affects the performance of local government organizations. However, this is different from the statement of Indudewi et al., (2021) in the results of their research which states that organizational culture in a high context has no effect on government performance.

The government's provision of a sizeable budget for handling COVID-19 as well as regulations for the procurement of goods/services in the context of handling the impact of COVID-19 provides an opening for deviant behavior, because in the Circular Letter of the Head of LKPP Number 3 of 2020, one of which states that in the procurement process goods for the purpose of handling covid-19 are carried out by a direct appointment mechanism. So that the role of government management in making decisions related to the budget is very large. Therefore, the inability of management to make the right decisions and at the right time can result in a failure in the organization (Sihombing, Nasirwan, and Situmeang, 2020). Making the right budget decisions can improve government performance, as stated by Indudewi et al., (2021).

In the decision-making stage, including in terms of the budget, information, both financial and non-financial, is needed that can be generated by an information system. One of the information systems in question is an accounting information system. An accounting information system is a collection of human resources and equipment set to convert the data obtained into information that is conveyed to different decision makers (Widjajanto, 2001), so that it can lead to better decision making by managers (Hanafi and Taleei, 2015), as well as influencing the decision making of the annual work program budget (Sihombing et al., 2020). In addition, accounting information systems not only help management to recognize the potential benefits of investments, but also improve business performance (Shahan et al., 2015), and improve local government performance (Molan and Priyadi, 2020).

The use of accounting information systems as a financial management tool in the Banten Provincial government has been implemented for a long time. Where for the last 3 years, 2018 to 2020, there have been using an application that is already running quite well, namely the Planning, Budgeting, and Reporting Management Information System (SIMRAL) as an information system that integrates the stages of planning, budgeting and administration in one system. However, at the end of 2020, the regional government was indirectly forced to switch to a new system, namely the Regional Development Information System (SIPD), as a follow-up to the Minister of Home Affairs Regulation Number 70 of 2019. The change in the accounting information system had an impact on the delay in the budgeting and administration process. finance in the government of Banten Province. It is feared that this will have an impact on the budget decision-making process and the level of performance of the Banten Provincial government. 
Budget decision making is one of the efforts to achieve organizational performance by using a systematic process in choosing alternatives. This process can be assisted by an accounting information system, because accounting information systems can produce quality information (Ahmad and Al-Sybiel, 2019). Better decision making by managers is influenced by a reliable accounting information system (Hanifi and Taleei, 2015, and Wang and Huynh, 2014). In addition, making the right budget decisions produced by a good accounting information system, can improve government performance. The basis for making budget decisions, apart from being supported by an accounting information system, must also be based on a good organizational culture (Jalal, 2017), because organizational culture serves as a behavioral guide for its members to overcome external adaptation problems. So that the better the habits embedded in the organization, the better the decisions taken (Sihombing et al., 2020).

Based on the discussion above, the authors see that accounting information systems and organizational culture are not optimal in influencing organizational performance, because achieving performance targets requires leadership intervention to make decisions. The accounting information system and organizational culture provide alternative choices and assumptions to leaders who are believed by the organization in making decisions, one of which is in terms of making budget decisions.

This research is a continuation of previous research, namely research conducted by Indudewi, Rahmawati, Probohudono, and Muthmainah (2021). This research was developed by adding the variables studied, namely the accounting information system variable, and the organizational culture variable as a reflection of the cultural context variable. Previously, research on the relationship between accounting information systems and organizational performance was mostly done in the private sector, while research on public deposits was rarely done. This research aims to determine and analyze the role of budget decision making as a mediator of accounting information systems and organizational culture on the performance of government agencies in Banten Province.

\section{Research Method}

This research is a quantitative research. The subject of this research is the State Civil Apparatus (SCA) who occupy the positions of echelon II, echelon III, and echelon IV in 15 Regional Apparatus Organizations in the Banten Provincial Government, totaling 124 employees.

This research uses a survey method with a questionnaire instrument to collect data. Data collection in this research was carried out by distributing questionnaires to respondents directly. This research uses one endogenous variable, namely the performance of government agencies, one mediating variable, namely budget decision making, and two exogenous variables, namely accounting information systems and organizational culture.

The data collection method was carried out by distributing questionnaires to State Civil Apparatus at 15 Regional Apparatus Organizations of the Banten Provincial Government. The 
number of questionnaires was obtained 124 copies distributed and only 66 copies of the questionnaires could be processed

The main theory that underlies this research is Stewardship Theory. Stewardship theory reflects the relationship between the principal (owner) and the steward (manager) (Davis et al., 1997 in Ghozali, 2020), where the steward behaves in accordance with the interests of the principal. Stewards are motivated to maximize organizational performance, to satisfy the interests of the principal. An organizational structure that accommodates and influences steward behavior choices helps facilitate maximum performance for the company. In stewardship theory, organizational culture is oriented towards the involvement of collectivism. Where the government in meeting its performance targets required community participation.

According to Murwaningsih (2009), stewardship theory describes the existence of a strong relationship between satisfaction and organizational success. In a government, which acts as a steward is the government itself,because the government is a public servant. So that in stewardship theory, the government is a steward (servant) with a function as a resource manager, and the people as the principal are the owners of the resources. In Raharjo (2007), this stewardship theory assumes a strong relationship between organizational success and owner satisfaction. This also applies in the local government environment, where a government performance (steward) is considered good if it has been able to provide good service to the community (principal). Public sector organizations have the goal of providing services to the public and being accountable to the public (public). Raharjo (2007) also states that the theory of stewardshiphas psychological and sociological roots designed to describe managers as steward(waiter). Theorystewardshipdescribes the situation of managers who are not motivated by individual goals and self-interest but are more focused on their primary outcome goals for the benefit of the organization or are more concerned with the interests of the organization.pricipal. So that when the interests of the community and the government are not the same, the government will try to fulfill the interests of the community rather than against it.

An effort to meet the interests of the community, the government in making decisions must have good values and norms as behavioral guidelines in determining decisions. In addition, it must also be supported by reliable information, both financial information and non-financial information, so that it can achieve the expected performance in accordance with the wishes of the community (principals).

This research wants to know and analyze how the role of budget decision making as a mediator of accounting information systems and organizational culture on the performance of government agencies.

Based on grand theory, previous research, and research hypotheses, the framework of thinking can be illustrated in Figure 1. 


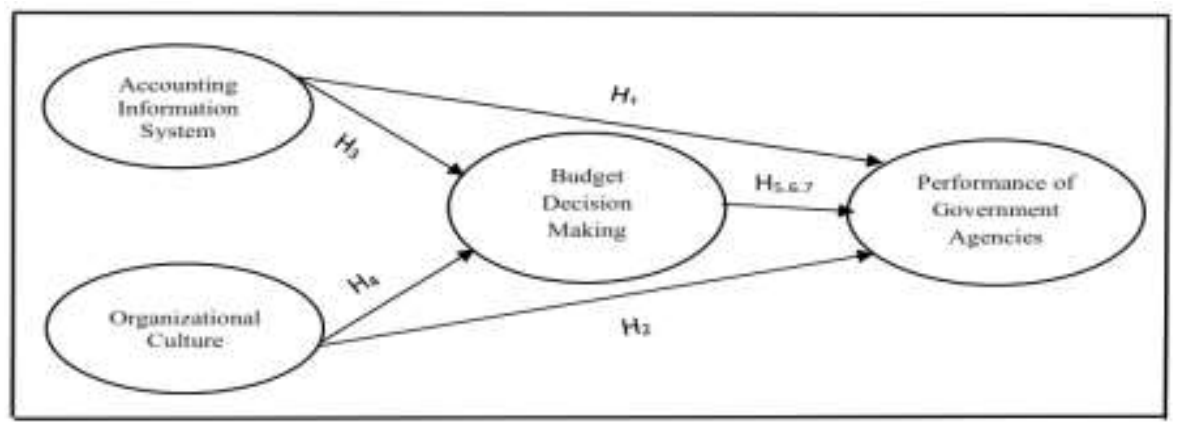

Figure 1. Theoritical Framework

\section{Result and Discussion}

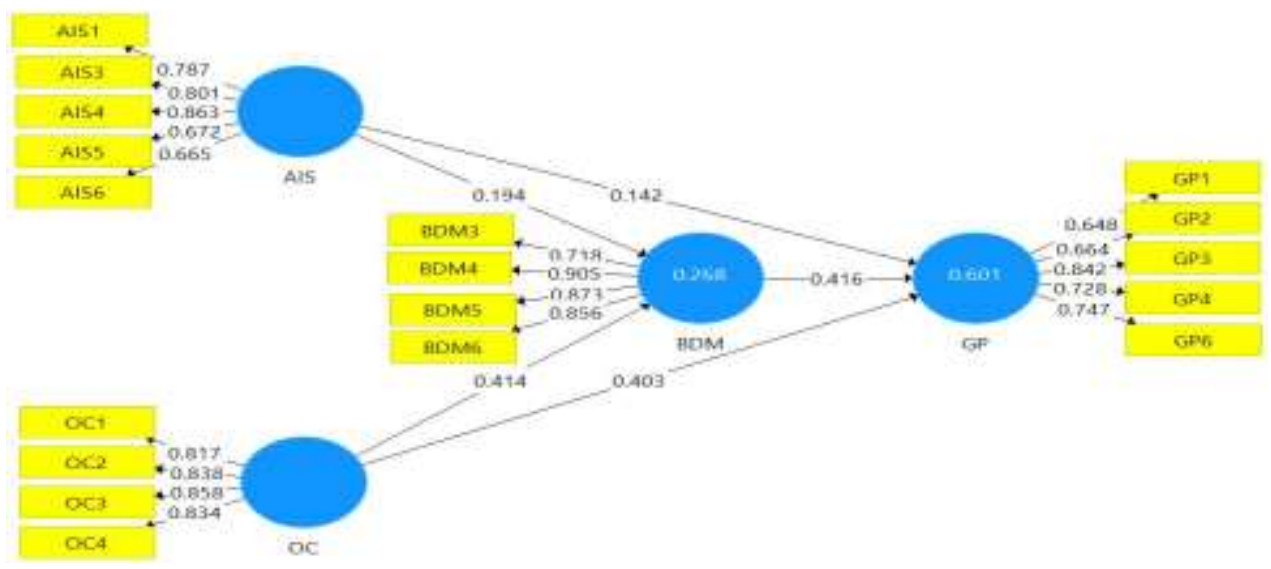

Figure 2. The Algorithm Model of SmartPLS

Table 1. Path Coefficients

\begin{tabular}{|c|c|c|c|c|c|}
\hline No & Hypothesis & $\begin{array}{c}\text { Original } \\
\text { Sample (O) }\end{array}$ & $\begin{array}{c}\text { T Statistics } \\
(|\mathrm{O} / \mathrm{STDEV}|)\end{array}$ & $\begin{array}{c}P \\
\text { Values }\end{array}$ & Description \\
\hline & Accounting Information System & & & & Not \\
\hline $\mathrm{H} 1$ & $\begin{array}{c}\rightarrow \text { Performance of Government Institution } \\
\text { Organizational Culture }\end{array}$ & 0.142 & 1,680 & 0.094 & Accepted \\
\hline $\mathrm{H} 2$ & $\rightarrow$ Performance of Government Institution & 0.403 & 3,422 & 0.001 & Accepted \\
\hline H3 & Accounting Information System & & & & \\
\hline H4 & $\begin{array}{c}\rightarrow \text { Budget Decision Making } \\
\text { Accounting Information System }\end{array}$ & 0.194 & 2.065 & 0.039 & Accepted \\
\hline & $\rightarrow$ Budget Decision Making & 0.414 & 4,193 & 0.000 & Accepted \\
\hline
\end{tabular}




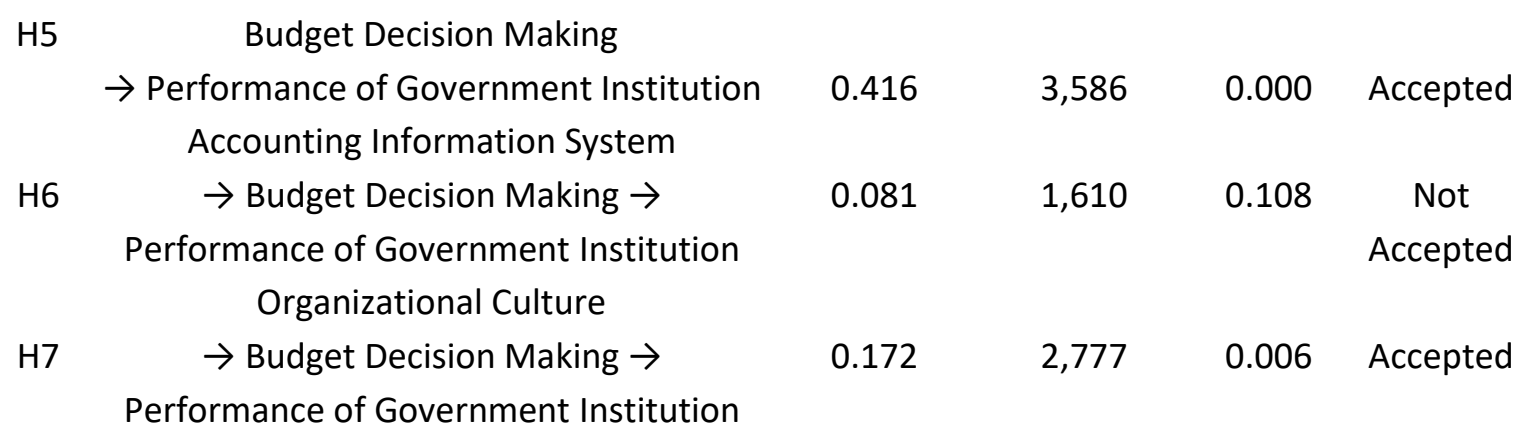

Source : Output of SmartPLS (2022)

Based on the results of testing the research hypothesis in the table above, it was obtained that the $t$-count on the research hypothesis 1 was $<1.96$ and the $p$-value of the research hypothesis $1>0.05$. This shows that $\mathrm{H} 1$ is rejected, so that hypothesis 1 in the research is not proven or cannot be accepted. Meanwhile, for the results of testing hypothesis 2 to hypothesis 5 research in the table above, the t-count on the research hypothesis is $>1.96$ and the $p$-value of the research hypothesis is $<0.05$. This shows that the research hypothesis $2,3,4,5$ is proven or can be accepted.

\section{Accounting Information System on the Performance of Government Agencies}

The coefficient value of the accounting information system on the performance of government agencies is 0.142 , and the t-statistical value is $1.680<1.96$ and $p$-value is $0.094>$ 0.05 , then $\mathrm{H} 1$ is rejected. These results indicate that the accounting information system has no effect on the performance of government agencies.

This shows that whether or not the existing Accounting Information System does not affect the Performance of Government Agencies. The State Civil Apparatus (SCA) within the Banten Provincial Government does not make an accounting information system the dominant tool to support government performance. As long as there are resources that are owned and managed to achieve goals for the benefit of the community, the government's performance can be achieved. In Stewardship Theory, a Steward (government) is motivated to maximize organizational performance, so that it can satisfy the interests of principal (public). So whether or not an existing accounting information system is not an obstacle for the government to be able to provide the best service to the community.

The results of this research are in line with previous research conducted by Sadad, Pituringsih and Irwan (2016) which stated that accounting information systems have no effect on government performance, and Ahmad and Sybiel (2019) based on their research in the SME industry in Jordan, concluded that information systems accounting has no significant effect on company performance. However, this research contradicts the results of previous studies which proved that accounting information systems are effectively used to improve organizational 
performance (Ismail, 2009), business performance (Abu Shahan et al., 2015), and local government performance (Molan and Priyadi, 2020).

\section{Organizational Culture on the Performance of Government Agencies}

The coefficient value of organizational culture on the performance of government agencies is 0.403 , and the t-statistical value is $3.422>1.96$ and the $p$-value is $0.001<0.05$, then $\mathrm{H} 2$ is accepted. These results indicate that organizational culture has a significant effect on the performance of government agencies.

Organizational culture is a set of assumptions, values and norms developed in an organization that serves as a behavioral guide for its members to overcome problems of external and internal adaptation. A strong organizational culture supports organizational goals, whereas a weak or negative culture inhibits or conflicts with organizational goals. The results of this research are in accordance with the theory, where a better organizational culture in the Banten Provincial government can increase government performance. The organizational culture that exists within the Banten Provincial government can influence the way employees behave, how to translate work, and how to work together between employees, so as to realize better government performance.

The results of this research are in line with previous research conducted by Fadhlurrohman, Budiman, and Khairina (2021), Sadad, Pituringsih and Irwan (2016), and Syahputri et al., (2019) which stated that organizational culture affects the performance of local government organizations. However, the results of this research contradict Indudewiet al., (2021) based on his research in Regional Apparatus Organizations (RAO) at the Yogyakarta Special Region Government (DIY) which concluded that organizational culture in a high context had no effect on government performance.

\section{Accounting Information System for Budget Decision Making}

The coefficient value of the accounting information system on budget decision making is 0.194 , and the t-statistical value is $2.065>1.96$ and the p-value is $0.039<0.05$, then $\mathrm{H} 3$ is accepted. These results indicate that the accounting information system has a significant effect on budget decision making.

According to Azhar Susanto (2013:8), one of the functions of accounting information systems is to support the decision-making process. An accounting information system is a system designed to collect and display accounting information so that accountants and organizational executives can make informed decisions. As the respondent's answer, which is dominated by the answer, agrees on the output of the accounting information system in the form of financial reports which are used as evaluation material which is then used as the basis for decision making. Thus a good accounting information system will assist the government in planning, budgeting and administrative management so as to improve the quality of budget decision making. 
In line with the above concept, empirically several previous studies have proven that accounting information systems have an effect on budget decision making. As research conducted by Sihombing et al., (2020) in his research conducted on 72 educational foundations in Indonesia, which states that accounting information systems influence budget decision making (in this case work program decisions formulated in the form of an annual budget).

\section{Organizational Culture on Budget Decision Making}

The value of the organizational culture coefficient on budget decision making is 0.414 , and the t-statistic value is $4.193>1.96$ and the $p$-value is $0.000<0.05$, then $\mathrm{H} 4$ is accepted. These results indicate that organizational culture has a significant effect on budget decision making.

The results of testing this hypothesis are in line with the theory of organizational culture which states that organizational culture can affect the way a person behaves and acts. So that the better the habits embedded in the Banten Provincial government agencies, the better the decisions taken by decision makers in the Banten Provincial government environment. A good organizational culture can be a reference in making decisions, both in budget planning and in budget execution. As someone who has the authority to make decisions, he must have good norms and values, so that the decisions taken can be accounted for, so that they produce the right decisions, because important decisions, one of which is related to budget decisions are taken by top management.

In addition, a good culture embedded in local government organizations can be signs or unwritten rules attached to employees so that they can avoid undisciplined behavior towards budget execution. So that acts of budget abuse in the Banten Provincial Government can be avoided.

In line with the concept above, empirically several previous studies have proven that organizational culture influences budget decision making. As research conducted by Indudewiet al., (2021) which proves that organizational culture can be a key part of local government budget decision makers. Likewise, according to Sihombinget al., (2020), which states that the better the habits embedded in the organization, the better the decisions taken in determining the work program budget.

\section{Budget Decision Making on the Performance of Government Agencies}

The value of the coefficient of budget decision making on the performance of government agencies is 0.416 , and the t-statistical value of 3.586> 1.96 and $p$-value $0.000<0.05$, then $\mathrm{H} 5$ is accepted. These results indicate that budget decision making has a significant effect on the performance of government agencies.

Decision making is a choice among various alternative options that are based on and on target in accordance with the expectations of the decision maker (Chaniago, 2017). This research provides evidence that the performance of government agencies is influenced by budget 
decisions taken, both from budget planning and budget execution. Budget planning and appropriate budget execution will improve government performance, both in terms of efficiency, effectiveness and service standards to the community. Therefore, decision makers within the Banten Provincial government, especially in planning and implementing the Banten Province Regional Revenue and Expenditure Budget (APBD) must be better and on target so that existing resources can be used optimally, which in turn will improve the performance of government agencies Banten Province.

Based on the majority of respondents who answered agreed, that the OPD work plan contained programs and activities that were beneficial to the community, it can be said that the budget decision making in the Banten Provincial Government was good and appropriate. It is in accordance with the principle stewardship theorythat the government asstewardin making decisions are not motivated by individual goals but rather are based on goals for the benefit of society.

Based on the results of the analysis in this research, it is evident that budget decision making has an effect on the performance of government agencies. As research conducted by Indudewiet al., (2021) which states that making the right budget decisions can improve government performance, and Wu et al., (2019) that decision making is a very important first step, even occupying a key position in achieving organizational performance.

\section{Budget Decision Making as Mediating Relationship between Organizational Culture and Performance of Government Agencies}

The coefficient value of the accounting information system on the performance of government agencies with decision making as a mediating variable is 0.081 , and the $t$-statistical value of $1.610<1.96$ and p-value $0.108>0.05$, then $\mathrm{H} 6$ is rejected. These results indicate that the accounting information system has no effect on the performance of government agencies with budget decision making as a mediator.

The results of this research indicate that budget decision making does not have a mediating role in the relationship between the influence of accounting information systems on the performance of government agencies in Banten Province. In other words, the performance of the Banten provincial government, either directly or indirectly, is not influenced by an accounting information system. Budget decision making is not able to bridge the accounting information system in an effort to improve the performance of government agencies.

\section{Budget Decision Making as Mediating Relationship between Organizational Culture and Performance of Government Agencies}

The coefficient value of organizational culture on the performance of government agencies with decision making as a mediating variable is 0.172 , and the t-statistical value is 2.777 $>1.96$ and $p$-value is $0.006<0.05$, then $\mathrm{H} 7$ is accepted. These results indicate that organizational 
culture affects the performance of government agencies by making budgetary decisions as a mediator. Based on the results of the calculation of the VAF value, the VAF value is $0.348(34.8 \%)$. If the VAF value is $>80 \%$, it shows the mediating variable as full mediation. If the VAF is between $20 \%-80 \%$, it can be categorized as mediation Partial. But if VAF $<20 \%$, it can be concluded that there is almost no mediating effect (Hairet al., 2013). So based on the VAF value of $34.8 \%$, it is included in the category of partial mediation because the VAF value is between $20 \%-80 \%$.

Based on the analysis above, it shows that budget decision making functions as a partial or partial mediator for the influence of organizational culture on the performance of government agencies. A good culture within the Banten Provincial government can improve the quality of budget decision making, which in turn will improve government performance. Because with a good culture, it will produce good and well-targeted budget decisions, so that the available budget or resources can be managed and utilized optimally for the benefit of the community, which in turn will improve government performance. Thus, it is expected that all employees within the Banten Provincial government, both those who have the authority or not in making budget decisions, must have good norms and values, so that decisions and actions taken can be accounted for, and produce the right decisions to achieve maximum performance targets.

In line with the above concept, empirically previous research has proven that decisionmaking acts as a mediator between organizational culture and the performance of government agencies. As research conducted by Indudewi et al., (2021), that budget decision making acts as a partial mediator of the relationship between organizational culture and government performance.

\section{Conclusion}

Based on the results of the discussion above, it can be concluded that In budget decisions making, a good organizational culture is needed and accurate accounting information can be sourced from a good accounting information system. In addition, this research provides evidence that budget decision making can act as a mediation of organizational culture on the performance of government agencies.

This research has a questionnaire return rate of below $60 \%$ which is probably due to the research being conducted during busy periods. This may reduce the accuracy of the results of this research. other than that this research is a data processing sourced from respondents' answers to the questionnaires given, so that the results of the questionnaire are a description of the respondents' perceptions at that time. Thus the results of the same research at other times may be different. Therefore, the results of this research cannot be generalized.

For the next research is expected to expand the scope used with a wider population an larger sample, so that better results are obtain. In this research, the variable of budget decision making is influenced by variables $X 1$ and $X 2$ only by $26.8 \%$, so there are many other factors that can influence budget decision making. Therefore, the next researcher should add other variables related to budget decision making. 


\section{References}

Ahmad, M.A., \& Al-Sybiel, A.O. (2019). Impact of Accounting System on Organizational Performance in Jordanian Indutrial SMEs: The Mediating Role of Knowledge Management. International Journal of Business and Social Science, 10(3), 99-104.

Anco (2017). Budaya Organisasi dan Pengambilan Keputusan. Shautut Tarbiyah, 36 (Mei), 1-18.

Ceschi, A. dkk. (2017). Decision-making processes in the workplace: How exhaustion, lack of resources and job demands impair them and affect performance. Frontiers in Psychology, 8(May), bll 1-14. doi: 10.3389/fpsyg.2017.00313.

Chaniago, A. (2017). Teknik Pengambilan Keputusan (pendekatan teori dan kasus). Jakarta: Lentera Ilmu Cendekia.

Davis, J.H., Schoorman, F.D., \& Donaldson, R. (1997). Toward a Stewardship Theory of Management. Academy of Management Review, 22(1), 20-47.

Fadhlurrohman, M.I., Budiman \& Khairina, E. (2021). Faktor-faktor yang Mempengaruhi Akuntabilitas Pemerintah Daerah (Studi Komparatif Pemerintah Kabupaten Bantul dan Kabupaten Sleman). Jurnal MODERAT, 7(2), 242-256.

Fatima, S., Ishtiaq, M., \& Javed, A. (2020). Impact of Accounting Information System on Corporate Governance: Evidence from Pakistan Textile Sector. Emerald Insight. International Journal of Law and Management. DOI 10.1108/IJLMA-07-2020-0212.

Ghozali, I. (2020). 25 Grand Theory. Teori Besar Ilmu Manajemen, Akuntansi dan Bisnis. Semarang: Yoga Pratama.

Ha, V.D. (2019). Impact of Organizational Culture on The Accounting Information System and Operational Performance of Small and Medium Sized Enterprises in Ho Chi Minh City. Journal of Asian Finance, Economics and Business, 7(2), 301-308.

Hanifi, F. \& Taleei, A. (2015). Accounting Information System and Management's Decisions Making Process. Growing Science. Management Science Letters 5, 685-694.

Indudewi, D., Rahmawati, Probohudono, A., \& Muthmainah (2021). The Role of Budget Decision Making in Mediating Trust, Social Ties, Cultural Context and Local Government Performance. Growing Science (Accounting Journal) 7, 1055-1066.

Ikamayasari, L., Akbar, M., \& Sari, E. (2020). The Effect or Organizational Culture and Communication in Decision Making by School Principals. International e-Journal of Educational Studies (IEJES), 4(7), 122-132.

Jalal, A. (2017). Impacts of Organizational Culture on Leadership's Decision- Making. Journal of Advances in Management Sciences \& Information System, 3, 1-14. 
Mokat, J.E.H. (2019). Kepemimpinan, Pengambilan Keputusan dan Diskresi. Jurnal Kajian Kebijakan dan Ilmu Administrasi Negara (Jurnal Administro), 1(1), 10-16.

Peraturan Presiden Republik Indonesia Nomor 29 Tahun 2014, tentang Sistem Akuntabilitas Kinerja Instansi Pemerintah.

Robbins, Stephen P \& Judge, Timothy A. (2013). Organizational Behavior Edition 15. New Jersey: Pearson Education.

Sadad, Pituringsih, E., \& Irwan, M. (2016). Pengaruh Budaya Organisasi, Kepemimpinan, Sistem Informasi Akuntansi, dan Standar Akuntansi Pemerintah terhadap Kinerja Organisasi pada Pemerintah Daerah Kabupaten Sumbawa. Journal of Auditing, Finance, and Forensic Accounting (JAFFA) 4(1), 30-45.

Sadjiarto, A. (2000). Akuntabilitas dan Pengukuran Kinerja Pemerintahan. http://puslit.petra.ac.id/journals/accounting/.

Shahzad, F., Xiu, G., \& Shahbaz, M. (2017). Organizational Culture and Innovation Performance in Pakistan's Software Industry. ScienceDirect. Technology in Society, 51, 66-73.

Sihombing, T.P., Nasirwan \& Situmeang, C. (2020). The Effect of Accounting Information and Organizational Culture on Decision Making. Budapest International Research and Critics Institute-Journal (BIRCI-Journal), 3(1), 522-530.

Supomo, B. \& Indriantoro, N. (1998). Pengaruh Struktur dan Kultur Organisasional terhadap Keefektifan Anggaran Partisipatif dalam Peningkatan Kinerja Manajerial: Studi Empiris pada Perusahaan Manufaktur Indonesia.

Susilo, W. \& Akbar, R. (2014). Peran Informasi Akuntansi sebagai Alat Akuntabilitas Internal, Evaluasi Kinerja Keuangan dan Pengambilan Keputusan Keuangan pada Instansi Vertikal Pemerintah Pusat. Accounting and Business Information System Journal, 2(2), Journal.UGM.ac.id/abis/article/view/59368.

Syahputri, dkk (2019). Factors that Influence the Reality of Performance Accountability in Government Institutions (Empirical Research in Government Deli Serdang). Budapest International Research and Critics Institute-Journal (BIRCI-Journal), 2(1), 263-270.

Undang-undang Republik Indonesia Nomor 23 Tahun 2014, tentang Pemerintah Daerah.

Uyar, A., Gungormus, A.H., \& Kuzey, C. (2017). Impact of The Accounting Information System on Corporate Governance: Evidance from Turkies Non-Listed Companies. Australian Accounting, Business and Finance Journal, 11(1), 9-27.

Wang, D.H.M. and Huynh, Q.L. (2014), The role of corporate governance in the link between management accounting system and firm performance, Asian Journal of Finance and Accounting, Vol. 6 No. 1, pp. 216-235. 
Wu, T. dkk. (2017). Top Management Teams' Characteristics and Strategic Decision-Making: A Mediation of Risk Perceptions and Mental Models. Sustainability (Switzerland), 9(12). 